\title{
An Appraisal of ASEAN's Readiness for Community Formation in December 2015
}

\author{
D. S. Ranjit Singh \\ School of International Studies \\ Universiti Utara Malaysia \\ ranjit@uum.edu.my \\ DOI: https://doi.org/10.32890/jis2015.11.6
}

\begin{abstract}
The ASEAN Community is expected to be formalized on 31 December 2015. The task of seeing the materialization of the much awaited project has fallen on Malaysia which is currently holding the Chair. The Malaysian team led by the Prime Minister, Dato' Sri Mohd Najib Tun Abdul Razak is not only making the necessary preparations to host the summit, but is also trying to complete the multitude of uncompleted tasks connected with the integration process. This paper outlines the major milestones that ASEAN has achieved since the organization began to toy with the idea of community formation in 2000 to the present time (October 2015). The paper will then examine the major challenges and shortcomings faced by ASEAN as well as some of the measures crafted by the organization to overcome them.
\end{abstract}

Keywords: Amalgamated community, pluralistic community, political integration, economic integration, societal integration.

\section{Introduction}

\section{The Genesis of the ASEAN Community Idea}

It would be appropriate to begin the discussion by first examining some of the factors that led ASEAN leaders to seriously consider forming an ASEAN Community. It may be said that the Asian Financial Crisis of 1997 and 1998 which adversely affected the region, provided the impetus for community formation. ASEAN members realized that they had to bring far greater integration of their economies if they are to weather the vagaries of the global economic and financial systems and any incidence of future crisis.

ASEAN leaders realized that the ASEAN Free Trade Area (AFTA), established in 1992 between the ASEAN - 6, Thailand, Malaysia, Singapore, Indonesia, Brunei and the Philippines ${ }^{1}$, was inadequate to deal with the problems of increased membership of the organization which took place from 1995 to 1999. By this time four new members had been added to ASEAN. They were Vietnam (1995), Myanmar (1997), Laos (1997) and Cambodia (1999). ${ }^{2}$ The economies of these countries lagged far behind the ASEAN -6 and had different structures and problems. The aim of AFTA to ultimately eliminate all tariff 
barriers among the member states and bring about greater integration of their economies therefore urgently needed a much more forward looking and sophisticated structure. This also provided the push for ASEAN to consider the vision of forging a regional community. There were external and global economic challenges to contend with as well. The most pressing issue was the rapid rise of China and India as the new economic power-houses of the world. Without greater economic cooperation and integration in the region, ASEAN would be unable to compete with the new giants; neither would it be able to benefit from their meteoric rise. To be globally competitive, the formation of an ASEAN Economic Community (AEC) at least, became inevitable. Linkages with extra-regional entities, especially the ASEAN+3 also required a higher degree of integration.

In terms of security, ASEAN also had to deal with a myriad of problems, both global and regional. There was the looming danger of international terrorism, the specter of disease pandemics, natural disasters, the changing nature of world political power structure, and regional territorial disputes, especially the unresolved maritime claims in the South China Sea.

Again, a regional security organ, called the ASEAN Regional Forum (ARF) which was created in 1994 as a multilateral security dialogue or forum, was basically formed in response to the uncertainties in the international order that resulted from the end of the Cold War in 1990. The political and security environment in Northeast Asia was particularly volatile and worrying which created a general feeling among the nations of the Asia Pacific for the creation a multilateral security dialogue to avoid a military confrontation. ${ }^{3}$ ASEAN saw the opportunity to take the initiative and be in the driver's seat instead of being made irrelevant and redundant. In this respect, and to be effective, ASEAN made a turnabout in its original policy of keeping out big power involvement in the region. The new stance was to get big powers involved actively in the security of the Southeast Asia. An active membership drive was launched with the result that soon ASEAN was able to get on board most of the powerful states in the Asia Pacific and beyond. ${ }^{4}$ Problems however remained. The ARF especially lacked regional organs of arbitration for the settlement of both intra and inter regional disputes. The rising tide of international terrorism which was now increasingly threatening regional security as evidenced by the 2002 Jakarta bombings also called for greater collective action. ASEAN thus needed to strengthen capacities in the region to "counter terrorism, drug trafficking......and other transnational crimes". ${ }^{5}$ A more comprehensive structure which would address political - security issues within ASEAN as well as tackle associated extra-regional problems, and which would subsume the ARF as one of its basic organs, was thus needed, and the answer lay in the idea of forging a regional community.

The desire to make ASEAN a people-oriented organization also provided a great momentum for community creation in the region. Such a change demanded concerted joint action to enhance human security by undertaking such measure as developing human resources; improving public health by the prevention of pandemics brought about by infectious disease; and by alleviating poverty and socio-economic disparities. ${ }^{6}$ 
Although the 1997 - 1998 Asian Financial Crisis provided the main stimulus for the adoption of the community idea, discussions on the subject began only in 2000 when leaders attending the $14^{\text {th }}$ ASEAN Informal Summit in Singapore broached the subject of speeding up the pace of greater cohesion and integration to strengthen the organization. ${ }^{7}$ Professor Amitav Acharya, in his seminal work Constructing a Security Community in Southeast Asia: ASEAN and the Problem of Regional Order published in 2001 also ignited further debate on the subject. ${ }^{8}$ In October 2002, Goh Chok Tong, the Prime Minister of Singapore at that time, suggested the formation of an ASEAN Economic Community to deepen regional integration to increase prosperity in the region. ${ }^{9}$ This idea was taken up by ASEAN leaders attending the ASEAN Heads of Government Meeting in Phnom Penh in November 2002.

It was however at the $9^{\text {th }}$ ASEAN Summit held in Bali in 2003 that the idea of forming a full-fledged ASEAN Community was explored and deliberated upon in a comprehensive manner. The outcome was the adoption of the Declaration of ASEAN Concord II whereby ASEAN leaders pledged to achieve an ASEAN Community by 2020, comprising three pillars, namely the ASEAN Security Community (ASC) which later became the ASEAN Political - Security Community (APSC); the ASEAN Economic Community (AEC); and the ASEAN Socio-Cultural Community (ASCC). ${ }^{10}$

The APSC was envisaged to bring political and security cooperation in the region to a higher plane to ensure a conflict-free, stable, peaceful, just, democratic and harmonious environment in the area. The major principle guiding its development was the reliance on peaceful means of settling conflicts. In terms of institutions, the ARF was to remain its primary driving force. For resolving intra-regional conflicts however, the High Council of the Treaty of Amity and Cooperation (TAC) was to be the main body. An ASEAN Maritime Forum was also established in 2003 to tackle the rising number of maritime territorial disputes in the region. ${ }^{11}$

The AEC was envisaged as developing into a single market and production base by 2015 , "with free flow of goods, services, investments and labour, and free flow of capital". The main objectives were to improve ASEAN'S competitiveness; enhance the investment environment in the region and narrow the development gap amongst ASEAN members especially between the ASEAN-6 and the new ASEAN-4. ${ }^{12}$

The focus of the ASCC is to bring about greater interaction and association amongst the peoples of the region by creating awareness of common values and each other's cultures. In this respect it is hoped that an ASEAN identity will emerge. It is also visualized that ASEAN will emerge as a people-centered organization leading to the development and enhancement of human resources which was the key to address the issues of poverty, equity and economic growth. Enhancing environmental sustainability and sound environmental governance was also considered vital to create a community of caring societies. Other areas highlighted for enhanced cooperation include addressing problems associated with population growth, employment, disaster management and public health, especially the control of infectious diseases such as HIV/AIDS and SARS. 
D. S. Ranjit Singh

\section{Progress of the Community Project, 2003-2015}

\section{The Vientiane Action Programme 2004}

Further steps at community building were taken when ASEAN leaders meeting at the $10^{\text {th }}$ ASEAN Summit at Vientiane in 2004, adopted the Vientiane Action Programme (VAP). The VAP was a six-year plan (2004-2010) for achieving the objectives of Concord II. In terms of strengthening the APSC, the VAP of 2004 further outlined the strategic thrust to be pursued. These included political development, shaping norms and values, conflict prevention, conflict resolution, and post-conflict peace building. In terms of the AEC, the VAP envisaged deepening economic integration and narrowing the development gap within the region, and increasing ASEAN's competitiveness in the global economy. In this respect, the VAP came up with the following main strategies for the period 2004-2010:13

a) to accelerate integration of eleven priority sectors by 2010

b) to remove as far as possible barriers to the flow of goods, services, skilled labour and capital by 2010

c) to intensify the implementation of the ASEAN Investment Area (AIA)

d) to eliminate tariffs for products by 2010 for ASEAN-6 and by 2015 for Cambodia, Laos, Myanmar and Vietnam (CLMV)

The leaders also agreed to establish the ASEAN Development Fund (ADF) to support other objectives of the VAP. ${ }^{14}$ There was also a noticeable change in the tone of ASEAN concerning its general objectives which in the past had centered on creating a strong, vibrant and resilient region, based on the principles of non-interference and consensus. Rather surprisingly, the VAP expressed the desire by ASEAN leaders to also enhance democracy and promote human rights in the region. ${ }^{15}$ There was a definite departure from the past.

\section{The ASEAN Charter, 2007}

From 2005 to 2005 ASEAN members were preoccupied with the drafting and adoption of the ASEAN Charter. It was only in 2003 and 2004, while ASEAN leaders were enthusiastically preparing the roadmap for the realization of the ASEAN Community, when it suddenly dawned upon them that ASEAN had in fact been operating since 1967 without a Charter or a Constitution. It was a stark reality that ASEAN leaders had to face. So, for the first time at the $10^{\text {th }}$ ASEAN Summit 2004, they stated categorically their intention to work towards the formulation of an ASEAN- Charter by setting up relevant mechanism for the purpose. ${ }^{16}$ This may be considered as an important milestone in the evolution of ASEAN. Subsequently, at the $11^{\text {th }}$ ASEAN Summit in Kuala Lumpur in December 2005, ASEAN leaders endorsed their earlier decision by issuing the Kuala Lumpur Declaration on the Establishment of the ASEAN Charter. The Summit leaders also formed the Eminent Persons Group (EPG), led by Malaysia's Tun Musa Hitam to make recommendations concerning the direction and contents of the Charter. The EPG report was presented to the $12^{\text {th }}$ ASEAN Summit held in Cebu, Philippines on 12 January 2007 whereupon a High Level Task Force (HLTF) led by 
Philippine Ambassador, Rosario Manalo was formed to draft the Charter. The $12^{\text {th }}$ ASEAN Summit, 2007 also decided to accelerate the formation of the ASEAN Community by 2015 instead of 2020 as agreed upon earlier. ${ }^{16}$ The final draft of the Charter was completed by the HLTF by October 2007 and submitted to the $13^{\text {th }}$ ASEAN Summit held in Singapore from 18-22 November 2007.

\section{Highlights of the Charter}

The Charter basically became the ASEAN Constitution which formalized, in a legally binding manner, all of ASEAN'S former commitments, treaties aspirations, purposes, principles, and institutions. It was also a document which contained new innovative ideas, visions, principles, and institutions reflecting the direction ASEAN was moving, especially toward an ASEAN Community by 2015. Some of the highlights of the Charter's provisions may be discussed here.

In the Preamble for example, in addition to other pronouncements, ASEAN'S commitment to establishing an ASEAN Community through enhanced regional cooperation and integration was emphasized. In this respect, the Bali Declaration of ASEAN Concord II, 2003 was endorsed. ${ }^{17}$ The Charter also created three new organs for the realization of the three community pillars of ASEAN. There were the ASEAN Political-Security Community Council (APSC); the ASEAN Economic Community Council (AEC); and the ASEAN Cultural Community Council (ASCC). The membership of each of these councils was to consist of national representatives from each of the member states. Each council was to meet twice a year, chaired by the relevant Minister from the member state holding the ASEAN Chair at the particular moment. Their task included implementing important decisions of the ASEAN Summit, and submitting reports and recommendations to forthcoming ASEAN Summit on matters under their jurisdiction. ${ }^{18}$

In the section on "Principles", many of the longstanding norms such as the renunciation of aggression, reliance on peaceful means of settling disputes, non-interference in the internal affairs of member states and enhanced consultations, were retained; but great emphasis was also given to "adherence to the rule of law, good governance, the principles of democracy and constitutional government", as well as "respect for fundamental freedoms", and "the promotion and protection of human rights". ${ }^{19}$

To give substance to the desire to promote and protect human rights and fundamental freedoms in the region, the Charter provided for the establishment of an ASEAN human rights body. This body was to begin functioning as soon as the ASEAN Coordination Council (which replaced the former ASEAN Ministerial Meeting of Foreign Ministers or $\mathrm{AMM}$ ), was able to convene to decide upon its terms of reference. ${ }^{20}$

Another matter given great emphasis was the desire to transform the hitherto statecentric organization to a people centered regional body. The Preamble and the section on "Purposes" abounds with aspirations to place the well-being, livelihood, welfare, prosperity 
and social progress of the people of the region at the centre of the ASEAN community building process. ${ }^{21}$

\section{The 2009 CHA-AM HUA HIN Roadmap for Realization of the Community, (2009-2015)}

From 2005 to 2007, ASEAN was preoccupied with drafting and adopting of the ASEAN Charter. Then, the $14^{\text {th }}$ ASEAN Summit, scheduled to be held in Thailand in November 2008 had to be postponed due to the violent anti-government protests by the "Yellow Shirts'.22 The $14^{\text {th }}$ ASEAN Summit was finally held in Cha-Am Hua Hin Thailand, from 28 February to 1 March 2009. The main achievement of this meeting was the adoption of the Cha-Am Hua Hin Declaration of the Roadmap for ASEAN Community (2009-2015). ${ }^{23}$

\section{Major Developments, 2009-2015}

From 2009 onwards, ASEAN was preoccupied with a number of issues. As far as enhancing the political-security pillar was concerned, a number of steps were taken. The main emphasis was on taking appropriate measures to strengthen security. In 2010 the ASEAN Defence Ministers Plus (ADMM-Plus) body was established to enhance the role of the ARF in the areas of Confidence Building Measures and Preventive Diplomacy. The ADMMPlus is an important platform to foster Constructive engagement between ASEAN and its Dialogue Partners on strategy, defence and security matters affecting the region. In 2011 further progress was made by this body when five Experts Working Groups (EWGs) were established on the following areas: ${ }^{24}$
a) Maritime security
b) Humanitarian assistance and disaster relief
c) Counter-terrorism
d) Military medicine, and
e) Peacekeeping operations.

At the same time (2011) the ASEAN Convention on Counter-Terrorism came to force after it had been ratified by all the ASEAN members.

The year 2011 was also a worrying one for ASEAN in other ways. A major crisis faced by the organization was the disruptive dispute between Thailand and Cambodia over ownership of a piece of land surrounding an 11 century Khmer temple called Preah Vihear Temple located at the border between the neighbours. The World Court ruled in 1962 that this ancient building, that is, the Preah Vihear Temple, belonged to Cambodia. The exact boundary of the surrounding grounds however remained in dispute. In 2008 the temple was granted UNESCO World Heritage Status. ${ }^{25}$ However, armed clashes between the two neighbours over the ownership of a small patch of territory surrounding the temple started in 2008 and 
caused much instability in the region and concern in ASEAN. The situation worsened in February 2011 when military clashes between the armed forces of both countries created what Hun Sen, the Prime Minister of Cambodia, called "a large-scale war" About 18 people lost their lives and some 85, 000 were displaced from their homes. ${ }^{26}$

The issue became a hot topic at the $18^{\text {th }}$ ASEAN Summit held in Jakarta in May 2011 and almost "derailed" the summit. ASEAN leaders at the meeting gave strong support to Indonesia as the holder of the current ASEAN chair to continue mediating in the bloody border dispute. Under effective leadership from Indonesia, a framework for a solution avoiding armed clashes was put in place. ${ }^{27}$ One result of this episode in terms of organ building for security purposes was ASEAN's agreement to establish an ASEAN Institute For Peace and Reconciliation (AIPR) to undertake research on the promotion of peaceful settlement of disputes in the region. This institute saw its birth in 2013. Thailand and Cambodia however did not use ASEAN mechanisms or structures to resolve their dispute. Instead, Cambodia referred the case to the International Court of Justice once again in 2011. In 2013, the said court finally ruled in Cambodia's favour, thus ending the hostilities between the two neighbours. ${ }^{28}$

Economic integration also charted some impressive achievements by 2011. The ASEAN Trade in Goods Agreement (ATIGA) was concluded in 2008 at the $14^{\text {th }}$ ASEAN Summit, but there were some outstanding problems that had still to be ironed out. The main issue was the refusal by Thailand and the Philippines to sign the pact as they could not agree over the sugar and rice import tariffs. It was at the $15^{\text {th }}$ ASEAN Summit, from 23-25 October 2010 that these two countries finally signed the agreement which came into force in May 2011. The national single window, a one-stop shop to speed customs clearance has been active in the ASEAN- $6 .{ }^{29}$

The ASEAN Comprehensive Investment Agreement (ACIA) also came into force in August 2010. AFTA was implemented on 1 January 2010 and it was reported that $99.5 \%$ tariff lines in CEPT - AFTA stood at 0 to $5 \%$ by this time. ${ }^{30}$ These are obviously beneficial and possibly necessary moves to create a single market in the region, but nationalist feelings are still very high amongst the nations of Southeast Asia and the free flow of labour especially, will be a most sensitive and vexatious issue to handle and implement.

In 2011 the ASEAN Framework Agreement on Services (AFAS) was inked to facilitate liberalization in trade services. Also concluded in the same year was the Mutual Recognition Arrangement (MRA) for greater mobility of skilled labour. This MRA however is limited in scope as only a few selective employment sectors are currently included. These are the engineering, architecture, accountancy, nursing, surveying, medical and dental services. ${ }^{31}$

The ASCC also saw some important developments. Again, a number of natural-calamities in regions surrounding ASEAN countries propelled the organization into some action. The most devastating calamity to hit Southeast Asia, and especially Sumatra, Thailand 
and Malaysia was the 2004 Indian Ocean Tsunami which claimed almost 250, 000 lives in these three countries alone. In 2008 the region again found itself utterly unprepared to deal with the catastrophe created by Cyclone Nargis in Myanmar and by a devastating earthquake in south-west China. The two disasters left more than 200,000 people dead or missing. A decision was taken to commence military exercises aimed at forging a regional disaster management task force. ${ }^{32}$ The efforts finally bore fruit with the establishment of the ASEAN Agreement on Disaster Management and Emergency Response (AADMER) on 24 December 2009. Its effectiveness however, remains to be seen. ${ }^{33}$

Otherimportant achievements of ASCC include the creation of the ASEAN Intergovernmental Commission on Human Rights (AICHR) at the $15^{\text {th }}$ ASEAN Summit at Cha-Am Hua Hin, Thailand, 23-25 October 2009. This is an important milestone in ASEAN'S efforts to "strengthen the promotion and protection of human rights in ASEAN". ${ }^{34}$ Further development in this field came with the establishment of the ASEAN Commission on the Promotion and Protection of Women and Children (ACWC) in 2010, which envisaged to protect the rights of women and children, "for their well-being, development, empowerment and participation in the ASEAN community- building process". ${ }^{35}$ In 2011, the AICHR started drafting the ASEAN Human Rights Declaration (AHRD) for the protection of human rights and the promotion of social justice in the region. This important document was completed and adopted in 2012. The Chairman's Statement of the 21 ASEAN Summit held in Phnom Penh on 18 November 2012 described this important achievement of ASEAN as follow: ${ }^{36}$

The adoption of the AHRD marks a new milestone for ASEAN in the implementation of the ASEAN Charter as well as highlights the strong commitment of ASEAN in the promotion and protection of human rights in the region as part of the process towards ASEAN Community by 2015.

\section{The 2012 Summit Crisis}

While ASEAN was charting quite an impressive progress in all the pillars of the ASEAN Community, the organization entered into choppy waters in 2012. Cracks, cleavages and divisions within the organization began to rock ASEAN solidarity and threatened to derail the $21^{\text {st }}$ Summit held at Phnom Penh in 2012. The fault-line was between those members who were pro-China, especially Cambodia, and those who opposed China's belligerent stance in the South China Sea, especially those Philippines and Vietnam. Chinese assertiveness in the South China Sea had led to naval battles between the Chinese navy and that of the Philippines and Vietnam. These two latter countries wished to include a categorical condemnation of Chinese aggression in the joint ASEAN communique which was to be issued at the conclusion of the 21th ASEAN Summit. Cambodia, however, the host, refused to accede to this demand. The AMM meeting at Phnom Penh was more turbulent and ASEAN suffered the ignominy of failing to issue a joint communique for the first in its history. ${ }^{37}$ 


\section{4: The Alarmbells are Sounded}

Despite the great strides made by ASEAN since 2003 in trying to reach its goals of achieving a fully integrated Community by 31 December 2015, serious outstanding problems remain. Most observers in 2014 therefore raised the alarm that ASEAN was not ready to assume full community status by the target date and the deadline should "be viewed not as the final destination but as a milestone on the slow and long journey" to a full-fledged Community. This view was expressed by Jayant Menon in his insightful article on the AEC in the New Straits Times of 15 October $2014 .{ }^{38}$ A similar opinion was expressed by Ong Keng Yong, the then (2014) Singapore's High Commissioner to Malaysia and a former Secretary-General of ASEAN from 2003 to 2008. In his view, when Malaysia assumed the chairmanship of the Organisation in 2015, the ASEAN Community will be formally instituted, but Malaysia would have the daunting responsibility of drawing up a comprehensive and proper plan for a "Post-2015 Vision" to take the ASEAN Community to its desired fulfilment. ${ }^{39}$

A major cause of alarm was the unreadiness of the AEC which is the cornerstone of the ASEAN Community. The AEC envisaged the creation of a single market and production base for the region. The greatest achievement in this direction has been tariff reduction after the implementation of AFTA on 1 January 2010. The result is that 70 per cent of intra-Asean trade is tariff free, but further progress is bogged down by the existence of NonTariff Barriers (NTBs) which are more difficult to eliminate..$^{40}$ Another major problem is the huge income and development disparities between the ASEAN-6 and the newer members consisting of Myanmar, Laos, Cambodia and Vietnam. This disparity has to be bridged somehow to have a meaningful AE.

Jayant Menon in his article on the AEC in the New Straits Times of 15 October 2014 also pointed out another weakness as follows: ${ }^{41}$

The AEC may be led by governments, but it cannot succeed without fully engaging business and the public at large. Meanwhile, efforts to prepare the private sector have enjoyed negligible success and public awareness is equally abyssal. This needs to change quickly if the AEC is to make a difference.

Indeed public awareness concerning the AEC and the other two pillars of the Community is greatly lacking, at least in Malaysia. This was the terrible discovery made by the International Trade and Industry Ministry of Malaysia (MITI) when it organized an engagement session with about 100 representatives of civil society in October 2014. The minister in charge of the said ministry, Datuk Seri Mustapa Mohamed who led the session was rather taken aback by this lack of knowledge on the part of the civil society representatives and remarked. ${ }^{42}$

It is a big embarrassment if we keep on talking about AEC but many people in Malaysia do not know about ASEAN is all about. 
Another political leader, Ong Keng Yong, Singapore's High Commissioner to Malaysia (2014) was apprehensive that ASEAN was not paying too much attention for bringing about a much desired people-centred Community. He complained as follows: ${ }^{43}$

We have been talking a lot about economic integration. We talk about political and security issues. But what about other socio-cultural issues such as education, healthcare, women's role and protection of children?

He was therefore of the view, as discussed earlier, that a great deal of work had still to be undertaken for the creation of a meaningful ASEAN Community and as such, a comprehensive "Post-2015 Vision" had to be put in the pipeline.

The fact that ASEAN was still grappling with a number of fundamental ailments was portrayed at the $25^{\text {th }}$ ASEAN Summit held in Nay Pyi Taw, Myanmar from 11-13 November 2014. The President of the Republic of the Union of Myanmar, U Thein Sein, in his address at the opening ceremony of the Summit, identified some of the urgent tasks that ASEAN needed to address before it could emerge as an integrated Community. These were as follows: ASEAN had to be serious about developing as a rules-based Community; ASEAN should maintain its centrality; ASEAN had to endeavor to sustain and enhance its economic dynamism and competitiveness; and it should take concrete steps to empower its institutions. ${ }^{44}$

Some of these concerns were taken up at the Summit itself. As far as maintaining ASEAN Centrality and promoting a rules-based Community were concerned, the Summit leaders emphasized adherence to norms and principles enshrined in major ASEAN agreements or treaties such as the ASEAN Charter, the Treaty of Amity and Cooperation (TAC) and the Declaration on the Conduct of Parties in the South China Sea (DOC). As usual there were more pronouncements than solid action. Another decision taken was to strengthen the ASEAN Secretariat, but again no concrete reforms were outlined. ${ }^{45}$

\section{5: Malaysia Takes the Chair. Can it Deliver the Goods?}

Since Malaysia took over the ASEAN Chair from Myanmar on 1 January 2015, ${ }^{46}$ the spotlight is on this country with high hopes and expectations from stakeholders that the new chair-holder will somehow wave the magic band, remedy the situation and bring the ASEAN Community to a successful fruition on 31 December 2015.

Bracing this heavy responsibility, Malaysian Government machinery and leaders have sprung into action. In mid-January 2015, ASEAN-Malaysia National Secretariat Deputy DirectorGeneral, Mohd Zamruni Khalid announced that Malaysia had prioritised eight strategies for implementation. On top of these priorities was of course the formalization of the ASEAN Community by 31 December 2015. Some of the other task areas identified were: to create a people-centred ASEAN Community; to strengthen ASEAN's institutions, especially the 
Secretariat; to improve, enhance and strengthen ASEAN economic performance and role; to promote regional peace and security; and to forge a meaningful Post - 215 ASEAN Community Development Vision. ${ }^{47}$

The next important event was the hosting of the $26^{\text {th }}$ ASEAN Summit by Malaysia, from 26 to 27 April 2015. Heads of State/Government of the ten member countries arrived in Kuala Lumpur on 26 April and were entertained to a grand dinner at the Kuala Lumpur Convention Centre by Prime Minister Dato' Sri Mohd Najib Tun Abdul Razak and his wife Datin Sri Rosmah Mansor. The Malaysian team also organized a number of activities for the delegates involving meetings with societal and business groups. One such programme was the convening of the $12^{\text {th }}$ ASEAN Leadership Forum for the youth. Speaking at the opening of the event, Dato' Sri Najib broached the subject of creating a "people-centred" Community in the following wors: ${ }^{48}$

We hope to focus on a people-centred ASEAN so that the grouping becomes more relevant to the ordinary people and develop a sense of Aseaness.

This concept was adopted as the overarching theme of the $26^{\text {th }}$ ASEAN Summit embodied in the Kuala Lumpur Declaration on a "People-Oriented, People-Centred ASEAN" issued on 27 April $2015 .{ }^{49}$ Incidentally, for the first time, the $26^{\text {th }}$ ASEAN Summit was held in two places and on the same day (27 April 2015), that is, at Kuala Lumpur and then at Langkawi. In the Chairman's Statement of the $26^{\text {th }}$ ASEAN Summit, the regions leaders fully supported the eight priorities outlined by Malaysia. However there were strong divisions among the member states concerning China's activities and assertiveness in the South China Sea. Najib, the Chairman, admitted that there were differences among ASEAN member countries on the matter, but said that these cleavages would not split the organization. ${ }^{50}$

\section{ASEAN how}

ever issued a strong statement pertaining to the situation in the South China Sea, with special reference to the land reclamation being undertaken by China in the area, although the latter was not mentioned by name. The Chairman's Statement on the issue is worded as follows: ${ }^{5} 1$

\section{Item 59}

We share the serious concerns expressed by some Leaders on the land reclamation being undertaken in the South China Sea, which has eroded trust and confidence and may undermine peace, security and stability in the South China Sea.

\section{$\underline{\text { Item } 60}$}

In this regard, we instructed our Foreign Ministers to urgently address this matter constructively including under the various ASEAN frameworks such as ASEANChina relations, as well as the principle of peaceful co-existence. 
D. S. Ranjit Singh

\section{$\underline{\text { Item } 61}$}

We reaffirmed the importance of maintaining peace, stability, security and freedom of navigation in and over-flight over the South China Sea. We emphasized the need for all parties to ensure the full and effective implementation of the Declaration on the Conduct of Parties in the South China Sea in its entirety: to build, maintain and enhance mutual trust and confidence; exercising self-restraint in the conduct of activities; to not to resort to threat or use of force; and for the parties concerned to resolve their differences and disputes through peaceful means, in accordance with international law including the 1982 United Nations Convention on the Law of the Sea.

\section{Item 62}

While noting the progress made in the consultations on the Code of Conduct in the South China Sea (COC), we urged that consultations be intensified, to ensure the expeditious establishment of an effective COC.

That this strong position on the dispute in the South China Sea was directed at China was revealed by Indonesian Foreign Minister Retro Marsudi, who said that ASEAN had been conveying such messages to China and would continue to do so. ${ }^{52}$

More meetings of the other organs and structures of ASEAN are being held to prepare the three pillars as much as possible before the next summit in December 2015.

\section{Assessing the "Completeness" of The ASEAN Community}

The general public and even informed persons do not seen to have a clear picture of what the ASEAN Community is going to be, or what it should be. All sorts of questions are being asked and various comments made without considering an accepted frame of reference. There is also a tendency to compare the degree of integration in the ASEAN Community with that of the European Union. These tendencies have often led to the perception that the ASEAN Community is not ready for take-off and that it will not be fully integrated by 31 August 2015. Even political leaders are making statements such as that the ASEAN Economic Community (AEC), the backbone of the bigger ASEAN Community will be fully integrated by $2025 .{ }^{53}$ Najib is even more ambitious and wants ASEAN to become a "borderless" fourth-largest economy of the world, and a fully integrated Community economically, politically and socially by $2050 .{ }^{54}$ What do all these statements mean? What is meant by full integration? There are three pillars of the ASEAN Community. Is the concept of full integration similar in all three instances? Do we just want a single market or do we want a political union like the European Union? To have a more meaningful evaluation of the "fullness" of our integration, we may employ three yardsticks. These are firstly, the conceptual and theoretical dimension; secondly the perspective of perceived 
and conceived ASEAN goals, programmes and visions; and thirdly the dimension of geopolitics and global developments.

In evaluating the degree and form of integration ASEAN has gone through and will go through in the immediate future, we must first take cognizance that integration can take different forms; the main manifestations being political, military, economic and societal. In this sense there seems to be a good correlation between theory and the three pillars of the ASEAN Community. We may now embark on this tricky question of evaluating ASEAN-Community's integration using the three yardsticks but following the three sectors of political security, economic and societal integration.

Political-Security Integratin

Theoretically, political integration according to Ernst Haas, is a process, ${ }^{55}$

whereby political actors in several distinct national settings are persuaded to shift their loyalties, expectations, and political activities toward a new centre, whose institutions possess or demand jurisdiction over the pre-existing national states.

Leon L. Lindberg describes political integration as follows: ${ }^{5}$

the processes whereby nations forego the desire and ability to conduct foreign and key domestic policies independently of each other, seeking instead to make joint decisions or to delegate the decision-making process to new central organs.

Then, again, political integration according to Karl W. Deutsch and his associates can lead to the formation of two types of International Communities.${ }^{57}$ One is called an Amalgamated Community. This happens when previously independent political units forge a single or larger entity or state with a common government. Examples of such unifications and political unions are the United States of America, the United Kingdom, the former Soviet Union; the European Union; and even the Federation of Malaysia. The important point to note in the creation of an amalgamated community is that independent and sovereign states surrender their powers to a central government, voluntarily or through force.

The second type of International Community is called Pluralistic. In this case the separate governments and independent states do not surrender their sovereignty to a new central government, and operate as an intergovernmental concert in conducting cooperation and collaboration.

In terms of security and military cooperation and integration a group of nation-states may form military alliances such as NATO, or the previous Warsaw Pact, or Malaysia's Five Power Defence Agreement. States indulge in the creation of military alliances as a response 
to perceived threats to their security and may choose either the role of "balancing" or "bandwagoning". 58

Looking from the vantage-point of the theories and models of integration, as well as from the perspective of goals and visions chosen and propounded by ASEAN leaders, and taking the historical and geo-political factors into consideration, we may now ask the question: where does ASEAN stand in terms of political-security integration?

It is obvious from utilizing the three yardsticks that ASEAN will not evolve politically into an Amalgamated Community like the European Union or a super-state in the immediate future. ASEAN has chosen to adopt the Pluralistic Community module where the ten member states will preserve their sovereignty, but will collaborate in a limited fashion with each other, as well as with extra-regional partners on specific issues. The organization does not envisage an ASEAN Parliament, nor a central authority which will take over power from the respective governments.

It is not surprising that ASEAN has taken such a stance. The region is made up of "young" nations who achieved independence (with the exception of Thailand) hardly seventy years ago. Nationalism and national sentiments are still very strong and it is not a novelty to see ASEAN members entering into conflicts with each other over issues pertaining to territorial rights, sovereignty, ill-treatment of their nationals by member states, and even ownership of cultural heritage. Geo-politically too, the region is extremely heterogeneous in terms of resources, political structures, ideologies, historical experiences, cultures, ethnicity, religious beliefs and modern day political alignments with extra-regional powers. Political unity, if it ever becomes a desired objective by ASEAN member states, is a far-off reality. Bearing in mind ASEAN'S preference for a pluralistic political structure as the umbrella module, and taking into cognizance the evolution of ASEAN'S security organs and mechanisms, it would be difficult to imagine ASEAN opting for a military alliance to cater for its security needs. The ARF, which is the backbone of the security pillar is a showcase of a multilateral security dialogue. Moreover it has almost all the major regional and global powers on board. How the ARF will or can become a regional military alliance with contending world powers as its members will be a difficult puzzle to fathom.

\section{Economic Integration}

There is less debate on the format of political-security integration although ASEAN is facing some serious geo-political-challenges which have caused divisions within the organization. The linchpin of the ASEAN Community project is economic integration. The AEC therefore has attracted a great deal of attention, especially from the business community and this has imposed a heavy burden on the planners to deliver the goods. We may again employ the three modes of measurements adopted above to gauge the degree of integration the AEC has achieved, and will achieve, by 31 August 2015 . 
The objective of the AEC is to create a single market and production base for Southeast Asia which will see a seamless flow of goods, services, and investments and a freer flow of capital and skilled labour. ${ }^{59}$

Datuk Seri Mustapa Mohamed, who is chairman of ASEAN Community's economic pillar, outlined some of the major tasks that still lay ahead for the realization of a fully integrated common market although 91 of the measures on the scorecard of the AEC Blueprint had been achieved. He also admitted that there had been a great deal of criticism, cynicism and disgruntlement from the business community, especially the ASEAN Business Council. Some of the issues raised by the business community pertained to the existence of NonTariff Barriers and the slow rate of liberalization in services. ${ }^{60}$ Liberalization of services means a process to open up domestic markets to foreign service providers and to remove or diminish discrimination against them vis-s-vis domestic suppliers. Although service liberalization might put domestic supplies at a disadvantage, there are benefits in the long-run. Liberalization creates opportunities for the inflow of foreign capital, expertise and technology to the domestic market and at the same time opens up foreign markets for expansion by local firms.

The $47^{\text {th }}$ ASEAN Economic Ministers Meeting (AEM), held in Kuala Lumpur on 25 August 2015 gave special attention to these concerns which were incorporated in the Blueprint for the AEC's takeoff on 31 December $2015 .{ }^{61}$ As mentioned earlier in this paper, however, the agreement on service liberalization or AFAS and the Mutual Recognition Agreement, both of which were concluded in 2011, opened up only a few sectors, namely the engineering, architecture, accountancy, nursing, surveying, medical and dental services. We must also remember that although the AEC will allow free movement of goods, services, and capital, there will not be total freedom of movement of labour like the EU.

In the last three years, ASEAN has also been trying to expand the free trade grouping beyond the region. This expanded free trade enterprise, if it materializes, is called the Regional Comprehensive Economic Partnership (RCEP). It is made up of the ASEAN-10 and six other partners with whom ASEAN has concluded Free Trade Agreements (FTAs). These six are China, India, South Korea, Japan, Australia and New Zealand. Progress within the RCEP has not been progressing well, the major stumbling block being the unwillingness of some members, chiefly Japan and China to give up some of their protectionist policies. However, hard bargaining and a herculean effort by the Malaysian International Trade and Industry Ministry, who organized the third meeting of the grouping on 25 August 2015, produced some encouraging results. An observer, Mergawati Zulfakar, has written on the matter in The Star as follows: ${ }^{62}$

It was tough but in the end all counties agreed to finalize the modalities for the goods sector to meet the aspiration to eliminate tariffs up to $80 \%$ in 10 years from the $65 \%$ [currently] when the RCEP eventually comes into force. 
According to information she obtained from one of the MITI officials, modalities for investment and services had been finalized and further discussion to trash out the technicalities will take place between officials only, without the intervention of ministers, in Busan South Korea in October 2015.

Theoretically, as observed above, a great deal of the AEC's processes conform neatly to the theories of Functionalism and Neofunctionalism as propounded by David Mitrany and Ernst Haas respectively.$^{63}$ On another note, it is important to draw our attention to the fact that yet another mega free trade area is being constructed, led by the United States which will cover a large area stretching from Malaysia to Chile. This large economic bloc is called the Trans-Pacific Partnership (TPP) and plans to include 12 countries, namely the United States, Canada, Mexico, Chile, Peru, New Zealand, Australia, Japan, Vietnam, Brunei, Singapore and Malaysia. The TPP was supposed to have been concluded two years ago, but a great deal of opposition domestically in many of the proposed member states, including the United States, and even in Malaysia, stalled the project. The United States then resolved its domestic legislative problems and President Barrack Obama put the finalization of the TPP on "fact tract". After protracted discussions and negotiations, the TPP Agreement (TPPA) was finally concluded on $5^{\text {th }}$ October 2015 in Atlanta USA. Member countries of the TPP have two years to ratify the agreement, before it takes effect in $2018 .{ }^{64}$ The point to note is that seven of the members of TPP, (Malaysia, Singapore, Brunei, Vietnam, New Zealand, Australia and Japan) are also members of RCEP and whether such a situation will in fact be a sure recipe for conflict of interest. How will these members resolve their conflicting obligations? To sum up the section on integration within the economic pillar, we must also bear in mind that ASEAN is not planning to adopt a common currency like the Euro in the EU; neither is the ASEAN Community going to open its borders for free movement of labour like the European model. And maybe for the better, seeing the bitter lessons the EU is learning from a completely integrated common market. So to judge whether the AEC is well integrated or not, the point of reference must be the set of goals and visions that ASEAN wishes to achieve.

\section{Societal Integration}

Now coming to the third aspect of the ASEAN Community's integration process, that is societal integration. In considering this aspect of the equation, a number of questions come to the fore. Have the various societies and citizen of the ten member states developed a sense of belonging to a larger ASEAN Community? Is there a feeling of ASEANESS amongst the people? Are societal groups taking an active part in contributing inputs to determine the type of larger community they want? Integration theories advocate a number of indicators or measurements of societal integration. Foremost among these are the intensity and volume of transaction flows and communication between the citizens of the different countries. The quality and quantity of these interactions are good indicators. Another measurement laid down by theories of integration are samplings of attitudes and sentiments taken from different groups of the population of the region. ${ }^{65}$ 
Sad to say, no serious research has been done to gauge the degree of the existence of the phenomena mentioned above. Generally speaking there has been very little participation by societal groups in the process of ASEAN Community building. The ASEAN Community has basically been an elitist project. The ASEAN leaders realised the presence of this fundamental flaw or shortcoming in their scheme and have come with some remedial measures such as the Kuala Lumpur Declaration on a "People-Oriented, People-Centred ASEAN". There is now an increased effort on the part of ASEAN leaders to engage with civil society; to organize programmes and activities for them; to establish instruments and organs for protecting human rights; and to undertake measures to improve their welfare and security. To my mind, although the new focus is paying more attention to societal needs and aspirations, it is still elitist driven. A true test of societal integration is the increase in connectivity between the people themselves and not just between the elitist leaders and society. People to people connectivity, however, is still in its infancy in ASEAN.

To sum up this section, we have to establish some criteria of measurement, or a referral point, for evaluating the degree and level of integration that the ASEAN Community Project has achieved and will achieve, otherwise, our pronouncements will be vague, faulty and inconclusive. In this respect, we cannot use the EU as the preferred benchmark for measurement of the integration processes within the conceived ASEAN Community because the two models are different. The EU is an Amalgamated Community; the ASEAN Community wishes to remain Pluralistic. Cognizance of this point is crucial for any meaningful evaluation. The application of the three criteria I have suggested in the paper, that is, theoretical modeling; ASEAN'S own declared aims and objectives, and geo-political factors, show beyond doubt that the ASEAN Community will not, at least in the foreseeable future, be a political union, nor a super-state supplanting the ten independent member states. Basically, the ten member states are not prepared to surrender their sovereignty and decision-making in foreign policy and defence to a new central regional authority. In this sense the ASEAN Community will remain a supra Intergovernmental Organisation with consensus decision-making on a joint basis on certain issues of vital regional interest. The ASEAN Community therefore offers a different model of integration than the EU, and may in fact avoid some of the grave pitfalls that the EU is now facing as a result of too much of centralization and unification. The greatest degree of integration, as spelled out by ASEAN'S goals and visions, is perceived to take place in the AEC. Even here, as pointed out earlier, there is no plan yet for a common currency; neither will national borders be thrown open to allow free flow of labour in the region. There will be a common ASEAN market allowing the free flow of capital, goods, and some selected services, but as discussed, some stumbling blocks, like Non Tariff Barriers, will have to be removed. In terms of societal integration and the achievement of a people-centred community, the organization has a long way to go, especially in the realm of people to people contacts and transactions. 


\section{Issues Needing Urgent Action}

In the final analysis, ASEAN, to my mind, has to give urgent and priority consideration to a number of issues which, if not handled judicially and effectively could cause irreparable harm to the ASEAN Community project.

\section{Finding a Lasting Solution to the Conflict in the South China Sea}

On top of the priority list of issues that need to be resolved urgently is the conclusion of the Code of Conduct in the South China Sea $(\mathrm{CoC})$. To my mind, the heightened tensions in the South China Sea resulting from the unsettled territorial claims of six claimants, coupled with China's current aggressive policy of assertiveness and land reclamations, ${ }^{66}$ pose the single most serious threat to the security and stability of the ASEAN region. Since 2001 ASEAN has been engaging China to push for the establishment of a set of rules for the settlement of outstanding conflicting claims in the South China Sea peacefully. These efforts bore fruit and culminated in the signing of the Declaration on the Conduct of Parties to the South China Sea (DOC) between China and ASEAN at Phnom Penh on 4 November 2002. ${ }^{67}$

The DOC basically emphasizes respect for national laws, adherence to the United Nations Convention on the Law of the Sea, 1982, (UNCLOS), peaceful settlement of disputes, and the non-use of force. Article 5 of the DOC especially calls for self-restraint among the claimants in the conduct of activities in the disputed area so as not to upset the peace and stability in the region. The DOC however is not legally binding. As a follow-up of the DOC therefore, ASEAN wished to come up with a legally binding instrument called the Code of Conduct in the South China Sea (CoC). ASEAN has been consulting China on this vital issue since 2002, but China has been reluctant to ink the agreement. My view is that ASEAN has to be more assertive in bringing China to sign a binding agreement so that the South China Sea dispute can be settled diplomatically and according to the rules of international law rather than brute force. This is a task that cannot be delayed, bearing in mind the explosive situation in the disputed area. A somewhat tougher stand was taken against China at the recently concluded $26^{\text {th }}$ ASEAN Summit which also urged for consultations to be intensified to ensure the "expeditious" establishment of the CoC. ${ }^{68}$ All eyes are on Malaysia as the current chair to bring the $\mathrm{CoC}$ to a conclusion.

\section{The Need to Maintain ASEAN'S Centrality}

The second most important issue that demands serious consideration, consensus and solidarity within ASEAN is the vexing problem of maintaining its centrality. This issue has emerged partly due to the rivalry of both the United States and China to impose their hegemony in the ASEAN region and partly due to ASEAN'S own ambitious designs. The United States policy of "rebalancing" initiated by President Barrack Obama in 2011 and the assertive policy of China in the region has had the effect of causing divisions within 
the ASEAN camp ${ }^{69}$ This issue, combined with ASEAN'S own ambitious extra-regional schemes such as the formation of a bigger East Asian Community, an enlarged ARF, and an expanded common market called the Regional Comprehensive Economic Partnership, will invariably burden the region with complex extra-regional problems as well as external interference. Will it not be wiser therefore, in the long-run, to concentrate on a more compact, people-oriented and more independent purely Southeast Asian Community of ten nations rather than bringing on board, as is the case with many of ASEANS organs, an unlimited number of extra-regional players together with their interests, agendas, rivalries and interference?

\section{Stopping the Annual Haze Hazard}

Since 1997, the phenomena of the regional haze which has been reportedly originating from forest fires and hot-spots in Sumatera and Kalimantan has been periodically plaguing at least three countries, that is Malaysia, Singapore and Indonesia itself. The haze takes a heavy toll on the health and economy of the countries affected. In 2002 ASEAN adopted the Transboundary Haze Pollution Agreement to coordinate efforts to fight the fires. ${ }^{70}$ Indonesia however stalled ratification of the agreement for 13 years while the haze debacle went on unabated, triggering health alerts, school closures and airport closures in Malaysia and Singapore over the years. ${ }^{71}$ In January this year (2015), however, Indonesia finally ratified the Transboundary Haze Pollution Agreement.

Under the 23-page agreement, the governments of the ten ASEAN countries are required to cooperate in developing and implementing measures to prevent and monitor transboundary haze pollution as a result of land and forest fires, and to control sources of such fires. When the transboundary haze pollution originates from within their territories, the governments are obliged to respond promptly to a request for relevant information or consultations sought by any state affected by the haze. The member states are also expected to take legislative, administrative or other measures to fulfil their obligations under the agreement. In addition, the treaty provides for setting up a coordinating centre and a fund for transboundary haze pollution control. ${ }^{72}$

Malaysia has been cooperating actively with Indonesia to find a solution to the problem and a memorandum of understanding is expected to be signed at the end of this year between the two countries. The haze crisis in October 2015 was so bad that it was considered to surpass even the 1997 levels. ${ }^{73}$ No solution however is in sight yet.

\section{Conclusion}

Starting from very humble and insignificant beginnings, and often faced with insurmountable challenges since its inception in 1967, ASEAN has indeed emerged to be a very successful and influential player on the international stage, packing a political and diplomatic punch 
D. S. Ranjit Singh

far in excess of its actual military and economic power. Pure persistence and a great deal of goodwill has seen the association move from stage to stage, improving, and improvising. With its great innovative spirit, creativity, and even pragmatism, ASEAN has produced unique ideas, structures and processes of conflict management and diplomacy with which it has not only been able to steer the beleaguer region away from conflict to relative stability and prosperity, but has also extended its influence and leadership to the AsiaPacific Region. From 2003 onwards the Organisation became enchanted with the idea of Community formation. Originally scheduled for realization in 2020, the grand vision was brought forward for fruition in 2015. The pace was therefore speeded up resulting in the adoption of the Charter in 2007 which became the legal and institutional framework for the realization of the ASEAN Community by 2015 . Since then there has been steady progress in the three pillars of the Community. At the same time, the organization is facing some daunting problems on its journey towards the 2015 Vision. I strongly believe however that despite all these obstacles, foreboding and pessimism, the ASEAN Community project will be launched in December 2015, but will remain as an Intergovernmental Organisation similar to Karl W. Deutsch's model of a "Pluralistic" Community as distinct from an "Amalgamated" one. More urgent, however for ASEAN, is to tackle the debacle in the South China Sea and maintain its centrality vis-à-vis United States-China rivalry to remain a viable, stable and relevant organisation.

\section{End Notes}

1 ASEAN Secretariat .(2002). Southeast Asia a free trade area .pp. 1-7.

2 Jorn Dosh, \& Manfred Mols. (1998). Expanding ASEAN's conflict management framework in SEA: The broader dimension. Pacific Review, 11 (2).

3 Daljit Singh. (2000). Evolution of the Security Dialogue Process in the Asia-Pacific Region. In Derek Da Cunha (Ed.). Southeast Asian Perspectives on Security. Singapore: ISEAS, pp. 36-59.

4 Chairman's Statement. (1994, July 25).The First ASEAN Regional Forum. Bangkok, pp. 1-2 For a recently published comprehensive study on the ASEAN Regional Forum (ARF) see Mely CaballeroAnthony.(2005). Regional Security in Southeast Asia: Beyond The ASEAN Way, Singapore: Institute of Southeast Asian Studies.

5 See Press Statement by the Chairperson of The $9^{\text {th }}$ ASEAN Summit And The $7^{\text {th }}$ ASEAN +3 Summit Bali, Indonesia, \& October 2003 pp. 1-5; and Declaration of ASEAN Concord II (Bali Concord II), pp. 1-6.

6 Declaration of ASEAN Concord II (Bali Concord II), p. 4.

7 Chairman's statement. (2001, July 25). The Eight Meeting of The ASEAN Regional Forum Hanoi. pp. 4-5.

8 Amitav Acharya. (2001). Constructing a security community in Southeast Asia: ASEAN and the Problem of Regional Order. London: Routledge.

9 Alan Collins.(2003). Security and Southeast Asia: Domestic, regional and global issues, Singapore: Institute of Southeast Asian Studies. pp. 127-159.

10 See Press Statement by The Chairperson Of The $9^{\text {th }}$ ASEAN Summit And The $7^{\text {th }}$ ASEAN +3 Summit Bali, Indonesia, \& October 2003 pp. 1-5; and Declaration of ASEAN Concord II (Bali Concord II), pp. 1-6. 
11 Press Statement, $9^{\text {th }}$ ASEAN Summit, pp. 2-3.

12 Chairman's Statement of the 10 ${ }^{\text {th }}$ Summit, Vientiane, 29 November 2004, p. 1

13 See Vientiane Action Programme (VAP). (2004-2010). 10th ASEAN Summit, Vientiane. pp. 9-12.

14 Chairman's Statement of the $10^{\text {th }}$ Summit, Vientiane. (2004), p. 1.

15 See Goals and strategies towards realising the ASEAN community. (2004-2010). Vientiane Action Programme (VAP), , p. 6

16 Termsak Chalermpalanupap.(2007, April 4-5). ASEAN'S Preparation for ASEAN Community. Paper presented at the International Seminar on "Celebrating the $40^{\text {th }}$ Anniversary of ASEAN: ASEAN'S Steps to ASEAN Community”, Universitas Sebelas Maret, Solo Indonesia, p. 3, and Dian Triamsyah Djani. (2007, April 4-5). ASEAN In a Changing World. Paper presented at International Seminar on ASEAN at Solo, p. 1.

17 Chairman's Statement of the 13 ${ }^{\text {th }}$ ASEAN Summit, Singapore, 20 November 2007, pp. 1-5, and Preamble, Charter of the Association of Southeast Asian Nations, (Charter), pp. 1-2.

18 Article 9, Charter, pp. 12-13.

19 Principles, Article 2, Charter, pp. 5-6

20 See Article 8 and 14, Charter, pp. 11 and 18.

21 Preamble and Purposes, Article 1, Charter, pp. 1-4.

22 The Star. (2009, October 22).

23 Chairman's Statement of the $14^{\text {th }}$ ASEAN Summit, Thailand, 28 February - 1 March 2009, pp. 1-3.

${ }^{24}$ Chairman's Statement of the 19 $9^{\text {th }}$ ASEAN Summit, 17 November 2011.

25 The Star. (2010, August 17).

26 The Star Online (2011, May 9).

27 RSIS Commentary 87/2011, 2 June 2011, p. 2.

28 Chairman's Statement of the 18 $18^{\text {th }}$ ASEAN Summit, Jakarta, 7-8 May 2011, and Chairman's Statement of the $24^{\text {th }}$ ASEAN Summit, 11 May 2014. For report on the ICJ Judgement on the area around the Preah Vihear Temple, see The Star, 12 November 2013. P. 29.

29 New Straits Times. (2014, October 15).

30 The Star. (2010, April 8); and Chairman's Statement of the $16^{\text {th }}$ ASEAN Summit, 9 April 2010, p. 3.

31 The Star. (2014, October 14).

32 The Star. (2008, July 28). p. 45.

33 Chairman's Statement of the $16^{\text {th }}$ ASEAN Summit, Thailand, 9 April 2010, p. 4.

34 Chairman's Statement of the 15 th ASEAN Summit, Thailand, 23-25 October 2009, p. 1.

35 Chairman's Statement of the $16^{\text {th }}$ ASEAN Summit, Thailand, 9 April 2010, p. 4.

36 Chairman's Statement of the 21 $1^{\text {th }}$ ASEAN Summit, Cambodia, 18 November 2012.

37 Chairman's Statement of the $21^{\text {th }}$ ASEAN Summit, Phnom Penh, 2012; Also see Sunday Star, 28 April 2013, and New Straits Times, 6 August 2013.

38 Jayant Menon, New Straits Times, 15 October 2014.

39 The Star. (2014, October 25).

40 Yang Razali Kassim “ASEAN Community: Losing Grip over Vision 2015?”, RSIS Commentary 87/2011, 2 June 2011, RSIS Commentries, [RSIS Publication @ NTU.EDU.SG], pp. 1-3.

41 Jayant Menon. (2015, October 15). New Straits Times.

42 The Star. (2014, October 14).

43 The Star. (2014, October 25).

44 Statement by U Thein Sein at the $25^{\text {th }}$ ASEAN Summit Opening Ceremony, Nay Pyi Taw Myanmar, 12 November 2014 
45 Chairman's Statement of the 25 th ASEAN Summit, Nay Pyi Taw Myanmar, 12-13 November 2014

46 New Straits Times. (2015, January 28). p. 14.

47 New Straits Times. ( 2015, January 22). p. 12.

48 The Star. (2015, April 27). p. 17.

49 Kuala Lumpur Declaration on a People-Oriented, People-Centred ASEAN, 27 April 2015.

50 The Star. (2015, April 29).

51 Chairman's Statement of the 26t1 ASEAN Summit, Kuala Lumpur \& Langkawi, 27 April 2015. My emphasis.

52 The Star. (2015, April 29).

53 New Straits Times. (2015, August 21).

54 New Straits Times. (2015, April 24-25); and (2015, August 22).

55 See James E. Dougherty and Robert L. Pfaltzgraff, JR, Contending Theories of International Relations, Philadelphia: J. B. Lippincott Company, 1971, p. 433.

56 Ibid; p. 433.

57 Karl W. Deutsch et al., Political Community and the North Atlantic Area, Princeton: Princeton University Press, 1957, p. 58.

58 See Stephen M. Walt, The Origins of Alliances, Ithaca, New York: Cornell University Press, 1987, p. 5.

59 New Straits Times. (2015, April 29; and August 22).

60 New Straits Times. (2015, August 22)

61 The Star.( 2015,August 26).

62 Ibid.

63 Dougherty and Pfaltzgraff, Contending Theories of International Relations, p. 432-440.

${ }^{64}$ The Star. ( 2015, June 30); ( 2015, October 6) and Starbiz Week. ( 2015, 10 October), pp. 5 and 9.

65 See Dougherty and Pfaltzgraff, Contending Theories of International Relations, p. 455-457.

66 See The Star. (2015, January 22); ( 2015, May 29) and ( 2015, Augusut 7).

67 Chairman's Statement, ASEAN regional Forum, 2000, p.4.

68 Chairman's Statement of the $26^{\text {th }}$ ASEAN Summit, Kuala Lumpur \& Langkawi, 27 April 2015, items 59-61.

69 See New Straits Times. (2015, April 24) and The Star (2015, June 17).

70 New Straits Times. (2013, June 18).

71 New Sunday Times. (2015, September 20).

72 Sunday Star. (2015, September 20).

73 The Star. (2015, October 3). 